Proc. Estonian Acad. Sci. Biol. Ecol., 2001, 50, 3, 139-157

\title{
INTERNATIONAL MARINE SCIENTIFIC ACTIVITIES IN THE BALTIC SEA WITH SPECIAL REFERENCE TO ESTONIAN PARTICIPATION
}

\author{
Bernt I. DYBERN ${ }^{\mathrm{a}}$ and Stig FONSELIUS ${ }^{\mathrm{b}}$

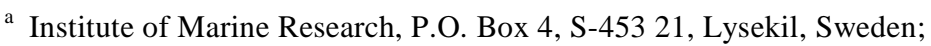 \\ Bernt-Ingemar.Dybern@ fiskeriverket.se \\ b SMHI Oceanographic Laboratory, Nya Varvet 31, S-426 71, V. Frölunda, Sweden; \\ fonselius@swipnet.se \\ Received 28 March 2001, in revised form 9 April 2001

\begin{abstract}
The development of international marine research in the Baltic Sea during the 20th century and Estonian participation are described. The organization of the International Council for Exploration of the Sea and its different working groups connected to the research in the Baltic Sea is explained. The founding and activities of the Conference of Baltic Oceanographers and the Baltic Marine Biologists are described. The international synoptic investigations of the Baltic and especially the "Cooperative Synoptic Investigation of the Baltic", "The International Baltic Year", "Baltic Open Sea Experiment", "Patchiness Experiment", and "The Skagerrak Experiment" and their results are briefly discussed. Some other recent international cooperation is also touched upon. Estonian participation in these activities is explained.
\end{abstract}

Key words: Baltic Sea, investigations, international organizations, Estonian participation, history.

\section{INTRODUCTION}

Marine research sensu strictu in the Baltic Sea goes back to the last half of the 19th century. Only four states then surrounded this sea: Denmark, Germany, Russia, and Sweden. From the 1870s international cooperation was established between universities and other institutions, not the least in the form of exchange of results of ship expeditions. Finland was under Russian rule, but it had its own marine organizations and could therefore participate in the international work. This growing international cooperation was first more or less attached to the interests of individual scientists. In Estonia, then also belonging to Russia, these were tied to the University of Tartu. K. E. von Baer and M. G. C. C. Braun were 
two of the most famous Estonian scientists conducting both hydrographical and biological investigations in the Baltic Sea (cf. Ojaveer et al., 2000).

However, towards the turn of the 19th century there was a growing awareness of the sea being a resource, and that this resource was not inexhaustible. This gave rise to an international cooperation also in a more official way between marine states, both in the Baltic area and elsewhere, and intensified hydrographical and marine biological investigations began. In 1878 a nauticalmeteorological conference on continuous hydrographic measurements by ships on regular routes, lightships, and coastal stations was held in Copenhagen with participants from Denmark, Norway, and Sweden. The reason for the establishment of nautical-meteorological institutions in the Scandinavian countries was the benefit of dividing up the work and the introduction of common principles for observations, performance, processing, and publishing of results. Measurements and observations of different parameters in air and water were discussed (Anon., 1878).

At the 14th Scandinavian science meeting in Copenhagen in 1892, a resolution on international cooperation suggested by professor O. Pettersson from Sweden was adopted (Anon., 1892). In that year the Danish and Swedish hydrographic commissions were established and in both countries hydrographic-biological investigations began. Real routine work was started in the 1890s. Observations on lightships had been performed since the 1870s. Temperature, salinity, and currents were measured daily.

Fisheries and related marine biological investigations (e.g. plankton studies) were carried out in the Baltic Sea at an early stage; however, it was not until the turn of the 19th century that real international cooperation began. This occurred with the founding of the International Council for the Exploration of the Sea (ICES). In cooperation with that organization international Baltic Sea Fisheries Congresses were arranged in 1910 and 1914. There was some Estonian input at least to the first of these congresses, held in Riga.

During the 20th century the Baltic Sea successively became the playground for several international organizations and a number of international scientific projects, each comprising all or most Baltic countries (Table 1). Some of these will be described briefly below from a historical viewpoint, including the Estonian connections.

Estonian research in the Baltic Sea (as well as in fresh waters) started, as mentioned, in the 19th century and has continuously gone on both under Russian and Soviet rule and during political freedom. A characteristic feature is that it has mainly been carried out by Estonians, even under occupation. When opportunity has been given scientists have taken part in international cooperation. An important part of the recent cooperation between Estonian and foreign scientists in the marine area has been in the Baltic international organizations and in international projects operating in the Baltic Sea, especially after World War II. The recent marine scientific capability and the international activities have 
successively grown from a rather low level during the USSR time to reach a peak at the end of the 1980s when the USSR ceased to dominate Estonia. After complete freedom in 1991 Estonia still retains this high level activity, although reorganizations and financial difficulties have, as also in other Baltic countries, to some extent hampered the full use of the potential capability.

Table 1. Important international organizations and projects in the Baltic Sea area

\begin{tabular}{|c|c|c|}
\hline \multicolumn{3}{|c|}{ International organizations } \\
\hline ICES & \multicolumn{2}{|c|}{ International Council for the Exploration of the Sea } \\
\hline $\mathrm{CBO}$ & \multicolumn{2}{|c|}{ Conferences of Baltic Oceanographers } \\
\hline BMB & \multicolumn{2}{|c|}{ Baltic Marine Biologists } \\
\hline IBSFC & \multicolumn{2}{|c|}{ International Baltic Sea Fisheries Commission (Warsaw Commission) } \\
\hline HELCOM & \multicolumn{2}{|c|}{$\begin{array}{l}\text { Baltic Marine Environment Protection Commission (The Helsinki } \\
\text { Commission) }\end{array}$} \\
\hline \multicolumn{3}{|c|}{ International projects } \\
\hline- & \multicolumn{2}{|c|}{ Cooperative Synoptic Investigation of the Baltic 1964} \\
\hline IBY & \multicolumn{2}{|c|}{ International Baltic Year 1969-70 } \\
\hline BOSEX & \multicolumn{2}{|c|}{ Baltic Open Sea Experiment 1977} \\
\hline PEX & \multicolumn{2}{|c|}{ Patchiness Experiment 1986} \\
\hline SKAGEX & \multicolumn{2}{|c|}{ The Skagerrak Experiment 1990-91 } \\
\hline \multicolumn{3}{|c|}{ Regional and other activities } \\
\hline Odra Bay & Gulf of Bothnia & Systems analysis projects \\
\hline Gulf of Gdansk & Monitoring projects & BASYS \\
\hline Gulf of Riga & Fisheries projects & BSLME/GEF \\
\hline Gulf of Finland & Modelling projects & Öresund \\
\hline
\end{tabular}

\section{THE INTERNATIONAL COUNCIL FOR THE EXPLORATION OF THE SEA}

This intergovernmental scientific body was founded in 1902 (Went, 1972). All the then four states around the Baltic Sea became members from the beginning. Also Finland could participate due to the fact that it had its own government, the tsar being Tsar of Russia and Grand Duke of Finland. Finland's membership was supported by Russian scientists, but for political reasons the Russian government after some years demanded that Finland should be excluded and be represented by Russian delegates.

Through ICES Baltic cooperation in hydrographic and marine fisheries investigations increased considerably. One of the early benefits was introduction of more standardized methods. After World War I (when the activities had been low) Estonia became independent and joined ICES in 1924, but withdrew after a couple of years in spite of being a "free member" (paying no fee) (Went, 1972). 
A certain contact was, however, kept with ICES with Estonia regularly reporting hydrographic data to ICES Annales Hydrographiques (Ojaveer et al., 2000).

World War II again prevented most international cooperation and after the war Estonian contacts outwards had to occur sparingly through USSR filters. The USSR joined ICES in 1955. The 48th ICES Statutory Meeting was held in Moscow in 1960, but Estonian scientists were not represented (Ojaveer et al., 2000). The Baltic Soviet republics, including Estonia, were during the 1960s and 1970s represented by M. N. Lishev, Baltic Fisheries Research Institute (BaltNIIRH). He was member of the ICES Baltic-Belt Seas Committee, which existed in 1954-66, handling mainly Baltic fish stock problems. He was also member of the Salmon and Trout Committee, succeeded by the Anadromous and Catadromous Fish Committee in 1966, both handling matters related to salmonids and eel. Other ICES committees had USSR representation, but at that time without any member from the Baltic republics, not even at a special Working Group on the Coordination of the Hydrographic Investigations in the Baltic Sea. There was, however, one exception. In 1968 a Working Group on Pollution of the Baltic Sea was established. A. Aitsam from the Institute of Thermophysics and Electrophysics in Tallinn represented the USSR. This group was the first one that gave an international overview of the environmental problems in the Baltic Sea (ICES, 1970) and made a presentation of these problems possible at the big international Marine Pollution Conference, arranged by FAO in Rome in 1970 (Dybern, 1972).

Aitsam then became representative of the Scientific Committee on Oceanic Research (SCOR), an international independent organization, on the ICES/SCOR Working Group on the Study of Pollution of the Baltic, active in 1975-86, which came to play a central role in Baltic environmental discussions. In 1983 the annual meeting of the ICES/SCOR group was held in Tallinn, preceeded by a Workshop on Patchiness.

In 1974 the ICES Baltic-Belt Seas Committee was substituted by the ICES Baltic Fish Committee and Lishev became BaltNIIRH member of the new body. Two working groups on Assessment of Pelagic and Demersal Fish in the Baltic were also established and E. Ojaveer, BaltNIIRH, Tallinn, became Estonian representative on the Pelagic group. In 1978 he became chairman of the group and stayed on for a decade under which important questions related to the fishery and investigation methodology were dealt with. In 1978 Ojaveer also succeeded Lishev as USSR member of the parent Baltic Fish Committee, and later, 198688 , he was chairman of the Committee.

At that time the political situation was becoming less tightened and it became easier for Estonian scientists to participate in international cooperation. For example, from 1987 M. Kangur represented the Estonian SSR on the ICES Baltic Salmon and Trout Assessment Working Group, and when the ICES/SCOR Working Group was dissolved in 1986 through the withdrawal of SCOR Aitsam became member of the succeeding ICES Working Group on the Baltic Environment and formally stayed on that group until 1993. 
In 1991 Estonia resumed its freedom and could make its own decisions on research and international cooperative activities. After dealing with some internal administrative problems, Estonia applied for membership in ICES, and this was granted in 1994. In a short time the country was represented on the Council, the advisory committees, ten subject committees, and in about a dozen working groups, dealing with fish stocks, fisheries, aquaculture, hydrography, and environmental problems. When ICES underwent a reorganization in1996-98 similar memberships were distributed on the new bodies. The importance of ICES for Estonia has been further demonstrated by the invitation to the organization to hold its 2003 Annual Conference in Estonia.

Estonian delegates to ICES were in 2000 E. Ojaveer and R. Aps. Members in ICES committees are J. Elken, A. Järvik, O. Kaljuste, M. Kangur, U. Lips, G. Martin, E. Ojaveer, H. Ojaveer, T. Raid, and T. Saat, all from the present Estonian Marine Institute. A number of other scientists have also been engaged in ICES activities.

ICES is a scientific organization dealing with the management of fish stocks, fisheries, and the marine environment in the North Atlantic area and hence in the Baltic area. Most activities are on the applied level. It is an intergovernmental body and cooperates mainly with other intergovernmental bodies. Originally the organization was a forum for scientific discussions and research cooperation. This in principle continues but among other things its advisory function has caused ICES to be increasingly bureaucratic. It now tries to overcome this situation by introducing a more pronounced ecosystem concept as the basis for all its considerations. ICES acts as an advisory body to the Baltic Marine Environment Protection Commission (The Helsinki Commission, HELCOM) and to the International Baltic Sea Fisheries Commission (Warsaw Commission, IBSFC). These are mainly administrative intergovernmental bodies dealing with environmental and fisheries problems respectively and as such depend on a scientific basis for their decisions. ICES also cooperates with the European Union, which can use ICES results as support for decisions on behalf of its member countries. Through ICES Estonian scientists are taking part in this advisory work.

Estonian scientists and administrators also take direct part in the work of both above-mentioned commissions. The Helsinki Commission runs a continuous monitoring programme (BMP) where all Baltic countries participate. Fixed stations are regularly sampled and the results are compiled at ICES in Copenhagen. The Commission arranges intercalibrations and cooperates closely with the other organizations in the Baltic Sea area. Every fifth year an assessment of the hydrographic and biological conditions and of pollution problems of the Baltic Sea area is published. The assessment work is carried out by members of ICES, BMB, $\mathrm{CBO}$, and the environment agencies of the different member countries. $\mathrm{H}$. Velner from Tallinn Technical University was Executive Secretary of the Commission during the period 1984-88. He has also been Chairman of the Commission for a period. L. Vaarja from the Fisheries Board, Tallinn, is currently (2000) Chairman of the Fisheries Commission. 


\section{CONFERENCES OF BALTIC OCEANOGRAPHERS}

After World War II the Hydrography Committee of ICES took the first steps to get the international work started again. At the ICES Council Meeting in Copenhagen in 1956 the Hydrography Committee discussed the problem and recommended on the basis of discussions between Finland, the Federal Republic of Germany, Sweden, and the USSR that detailed plans should be made. A Subcommittee on the Coordination of Hydrographic Investigations in the Baltic with I. Hela (chairman), J. Krey, B. Kullenberg, and V. A. Lednev was appointed. At that time there were seven independent states around the Baltic Sea. One of them, the German Democratic Republic, was for political reasons prevented from joining ICES. At a meeting in Helsinki in March 1957, where 26 scientists participated, it was decided to overcome this difficulty by forming a nongovernmental oceanographic organization in which all Baltic Sea countries could participate.

Hela suggested the name "Conference of the Baltic Oceanographers" for the organization (Matthäus, 1987). The main tasks of CBO were coordination of hydrographic work and water balance studies. CBO should meet every second year in different institutions of the Baltic Sea area. Between the conferences "Senior Scientists" should act as a steering committee for discussing problems of joint interest. The Subcommittee was later transformed to a Working Group with the task to be a permanent link between ICES and CBO. CBO has since then given recommendations for many important activities in the Baltic Sea. One of the first was the suggestion that 17 international deep stations should be established to be sampled when possible (Matthäus, 1987). This can be regarded as a beginning of a monitoring programme.

CBO functioned well and when the German Democratic Republic finally was admitted into ICES in 1975 the organization continued with the aim to further Baltic oceanography. The cooperation with ICES continued and when BMB (see next chapter) was founded, it was agreed that $\mathrm{CBO}$ and $\mathrm{BMB}$ should alternate with meetings in order to give hydrographers and marine biologists opportunities to participate in the meetings of both organizations and to avoid overlapping of the meetings (Table 2).

$\mathrm{CBO}$ stressed the importance of coordination of the measurements. For that purpose several intercalibration meetings were initiated with ships from different laboratories participating and physical-chemical and biological measuring methods were standardized as much as possible. The first meeting was arranged in Copenhagen in 1964, the second in Leningrad in 1966, and the third the same year in Copenhagen, where also ships from Norway and the UK participated. In 1977 a large intercalibration meeting was arranged in Kiel with 66 participants from 30 laboratories representing seven countries. The work was carried out during two weeks. For sampling five research vessels were available. An Intercalibration of Biological and Chemical Methods was held at the Askö laboratory in June 1974 and immediately after this a meeting on Biological 
Table 2. Biannual meetings of Baltic Oceanographers (CBO) and Baltic Marine Biologists (BMB)

\begin{tabular}{|c|c|c|c|c|}
\hline 1957 & CBO I & Helsinki, Finland & & \\
\hline 1959 & CBO II & Kiel, FRG & & \\
\hline 1962 & CBO III & Göteborg, Sweden & & \\
\hline 1964 & CBO IV & Warnemünde, GDR & & \\
\hline 1966 & $\mathrm{CBO} \mathrm{V}$ & Leningrad, USSR & & \\
\hline 1968 & CBO VI & Sopot, Poland & BMB I & Rostock, GDR \\
\hline 1970 & CBO VII & Helsinki, Finland & & \\
\hline 1971 & & & BMB II & Stockholm, Sweden \\
\hline 1972 & CBO VIII & Copenhagen, Denmark & & \\
\hline 1973 & & & BMB III & Helsinki, Finland \\
\hline 1974 & CBO IX & Kiel, FRG & & \\
\hline 1975 & & & BMB IV & Gdansk, Poland \\
\hline 1976 & CBO $\mathrm{X}$ & Göteborg, Sweden & & \\
\hline 1977 & & & BMB V & Kiel, FRG \\
\hline 1978 & CBO XI & Rostock, GDR & & \\
\hline 1979 & & & BMB VI & Århus, Denmark \\
\hline 1980 & CBO XII & Leningrad, USSR & & \\
\hline 1981 & & & BMB VII & Rostock, GDR \\
\hline 1982 & CBO XIII & Helsinki, Finland & & \\
\hline 1983 & & & BMB VIII & Lund, Sweden \\
\hline 1984 & CBO XIV & Gdynia, Poland & & \\
\hline 1985 & & & BMB IX & Turku, Finland \\
\hline 1986 & CBO XV & Copenhagen, Denmark & & \\
\hline 1987 & & & BMB X & Kiel, FRG \\
\hline 1988 & CBO XVI & Kiel, FRG & & \\
\hline 1989 & & & BMB XI & Szczecin, Poland \\
\hline 1990 & CBO XVII & Norrköping, Sweden & & \\
\hline 1991 & & & BMB XII & Helsingør, Denmark \\
\hline 1992 & CBO XVIII & St. Petersburg, Russia & & \\
\hline 1993 & & & BMB XIII & Riga-Jurmala, Latvia \\
\hline 1994 & CBO XIX & Sopot, Poland & & \\
\hline 1995 & & & BMB XIV & Pärnu, Estonia \\
\hline 1996 & CBO XX & Rønne, Denmark* & & \\
\hline 1997 & & & BMB XV & Mariehamn, Finland \\
\hline 1998 & CBO XXI & Warnemünde, Germany* & & \\
\hline 1999 & & & BMB XVI & Klaipeda, Lithuania \\
\hline
\end{tabular}

* The meetings in Rønne 1996 and Warnemünde 1999 were joint meetings organized by Baltic Marine Biologists, Baltic Marine Geologists, and Conference of Baltic Oceanographers.

and Physical Modelling was held in Stockholm. In August-September 1979 HELCOM, in cooperation with CBO and BMB, arranged a Biological Workshop in Stralsund with six research vessels from six countries participating. The second Biological Intercalibration Workshop was arranged in cooperation with the Baltic Monitoring Programme in Rønne on Bornholm in 1982 with seven research ships from seven countries. 
Tallinn scientists made occasional inputs into CBO already earlier, but from CBO XII in Leningrad in 1980 Estonian participation became regular. During the 1980s and 1990s about 35 scientists (mainly from the Institute of Thermophysics and Electrophysics, after the gaining of independence the Estonian Marine Institute) took part in one or more Conferences, presenting more than 50 papers and posters, some in collaboration with scientists from other countries. U. Lips was the first Senior Scientist representing free Estonia.

\section{BALTIC MARINE BIOLOGISTS}

During the 1950s and 1960s CBO dealt mainly with marine physics and chemistry, and in addition, with the nutrient conditions of the Baltic Sea. Many Baltic marine biologists, mostly those involved in basic research and based at universities, felt that they had no common forum for exchanging views and results. Scientists working with applied science were better satisfied by organizations such as ICES, intergovernmental commissions, committees, etc. The political dividing up of the Baltic countries into East and West further prevented the exchange. At the same time it was noticed that the marine biological methods used in the Baltic Sea were not uniform and that the results of investigations could be difficult to compare. In order to change these conditions to the better, a new organization, the Baltic Marine Biologists (BMB), was founded at a symposium in Rostock, German Democratic Republic, in September 1968 (Arndt, 1969) with the main aims in brief:

1. To further contacts and cooperation between Baltic marine biologists;

2. To further Baltic marine biological research, especially basic research;

3. To elaborate adequate and common methods for Baltic marine biological research.

This has been achieved by, among other things, arranging BMB symposia (every second year, Table 2), setting up working groups, workshops, etc. for different purposes, and organizing cooperative research projects and projects jointly with other organizations, all these activities led by a Steering Committee. As to the contacts between East and West BMB could join all Baltic countries already at an early stage. With scientists from the USSR this was at the beginning rather difficult and could mainly occur through correspondence. A few papers to BMB symposia were obtained from Estonian scientists in the 1970s and early 1980s. But gradually the exchange became freer and in 1986 the BMB Steering Committee could hold its annual meeting in Tallinn. In 1989 the Latvian scientist G. Andrušaitis became USSR member of the Committee. The real break-up of the ice came in 1990, when a Steering Committee meeting was held in Riga. The three Baltic republics then got one member each in the Committee. E. Ojaveer became member for Estonia.

When Estonia, Latvia, and Lithuania became free in 1991, they successively got three members each on the BMB Committee, for Estonia A. Järvekülg, 
H. Kukk, and E. Ojaveer. In 1999 A. Järvekülg was substituted by T. Saat. E. Ojaveer was president of BMB during the period 1995-97. The 13th BMB Symposium was held in Riga in 1993 and it was attended by about 40 scientists from all three Baltic states. Several got their contributions printed in the symposium volume (Andrušaitis, 1997).

The 14th BMB Symposium was held in Pärnu in 1995 and was attended by about 110 scientists, of which about 35 were from Estonia. This was the first time that a relatively large international marine biological meeting was arranged in Estonia, and Estonian scientists produced about a dozen papers in the symposium volume (Ojaveer, 1997). In all about 30-40 Estonian marine biologists have recently been involved in different BMB activities, most of them from Tallinn but some also from Tartu and Pärnu.

\section{INTERNATIONAL SYNOPTIC INVESTIGATIONS OF THE BALTIC}

With the founding of ICES in 1902 regular reporting and publication of oceanographic observations were started. Data were collected on fixed stations, including the most important deep stations, e.g. the Bornholm Deep, the Gotland Deep, the Landsort Deep, the Åland Deep, the Ulvö Deep, etc. The Baltic Sea was divided into different areas, which were monitored by Finland, Sweden, Denmark, and Germany. The main deep stations were divided between the countries so that every country got deep stations to measure. Russia did not have any available research ships, because the Russians had also to cover the Barents Sea (Fonselius, 2001).

All open sea measurements were disrupted during World War I. The measurements began again in 1921, but only a few stations were sampled every year. Best covered was the Gotland Deep. The results were published in the Annales Hydrographiques of ICES. Now Estonia, Latvia, Lithuania, and Poland had become free states and between the two world wars Baltic hydrological conferences outside ICES were arranged between 1926 and 1938 in Riga, Tallinn, Warsaw, Leningrad, Helsinki, and Berlin. The main items were the hydrometeorological station network, the levelling of tide gauges, data processing, and the water balance of the Baltic Sea. Even if Estonia was not a member of ICES, methods and equipment recommended by that organization were used in Estonian sampling (Ojaveer et al., 2000).

Several joint research programmes have been performed in the Baltic Sea after World War II. The first of these, the "Cooperative Synoptic Investigation of the Baltic", was carried out in August 1964 after planning by CBO and with assistance of ICES. The main objective was to study the short-time variations in the dynamics of physical and chemical parameters in the Baltic Proper, caused by meteorological processes. In this Programme 11 research ships (9 of them at anchor stations) and 2 lightships participated. Also four current moorings and 28 coastal stations were engaged (Fig. 1). Six countries - Finland, the Federal 


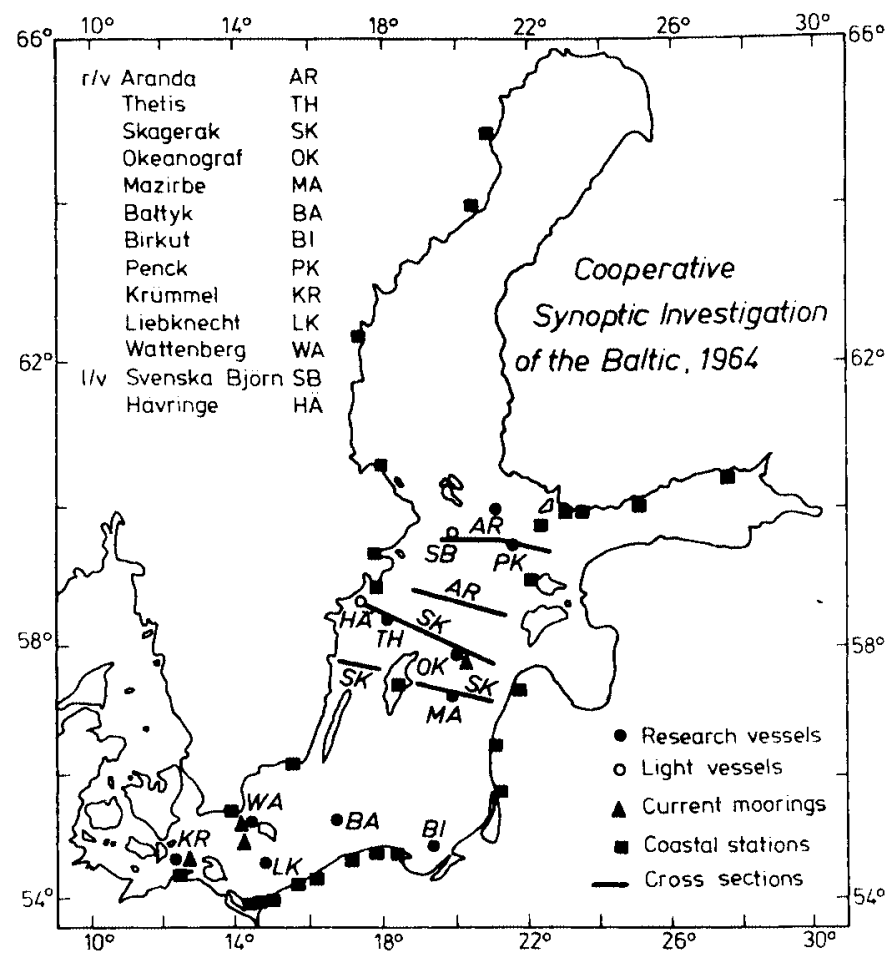

Fig. 1. Map showing the different sections, research vessels, lightships, current moorings, and coastal stations of the Cooperative Synoptic Investigation of the Baltic in 1964 (Matthäus, 1987).

Republic of Germany, the German Democratic Republic, Poland, Sweden, and the USSR - participated. Some principal results were presented at the CBO V in 1966. Further results have later been published on the kinetic energy distribution in the seiches range, etc. (Matthäus, 1987).

\section{THE INTERNATIONAL BALTIC YEAR}

At the V CBO in Leningrad in 1966, repetition of joint synoptic investigations in the Baltic Sea area was recommended to be continued and it was decided to ask the Swedish Senior Scientists to be in charge of the organization of a second international survey and to submit a draft programme for consideration at the VI CBO. The Swedish Senior Scientists suggested that a Baltic Year should be arranged. The relevant decision was adopted by CBO VI. In 1969-70 the International Baltic Year (IBY) was organized with the assistance of ICES and $\mathrm{BMB}$. According to the plans the national cruise programmes were coordinated so that a series of 39 stations, called BY-stations, in the Baltic Proper and the Gulf of Finland (Fig. 2) were sampled every month by one participating ship from 


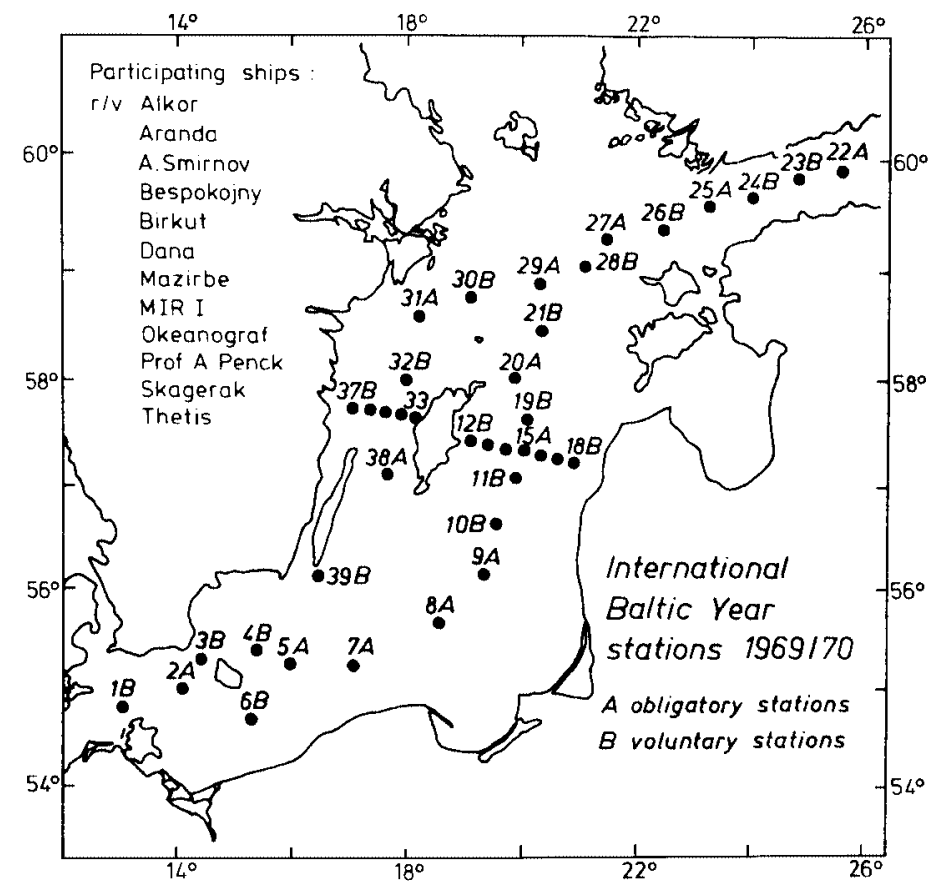

Fig. 2. Map showing the hydrographic stations of the International Baltic Year 1969-70 (Matthäus, 1987).

January 1969 to December 1970. All ships used the Gotland Deep as an anchor station and took water-series eight times a day during one week. Altogether 12 research ships participated in the IBY. The main purpose was to study the inflow of deep water and the oxygen conditions in the deeper layers. An inflow of oxygen rich water to the Gotland Deep and the turnover of the deep water were observed in February 1969 by the Professor Albrecht Penck from the GDR. The intensive and careful following of the deep water exchange process facilitated understanding of this process. The station network has later been used as a foundation for the Baltic Monitoring Programme of HELCOM.

\section{BALTIC OPEN SEA EXPERIMENT}

In 1974 the ICES/SCOR Working Group formulated future research tasks, important for better understanding of the Baltic Sea system in relation to pollution. The Baltic Open Sea Experiment (BOSEX) was performed with the assistance of CBO and BMB from 5 to 22 September 1977 in the central Baltic Proper south of Gotland in a $30 \times 30 \mathrm{~km}$ square (Fig. 3) with 11 research ships and scientists from 14 institutions representing all Baltic Sea countries. One of the ships was the Aju Dag from Tallinn. 


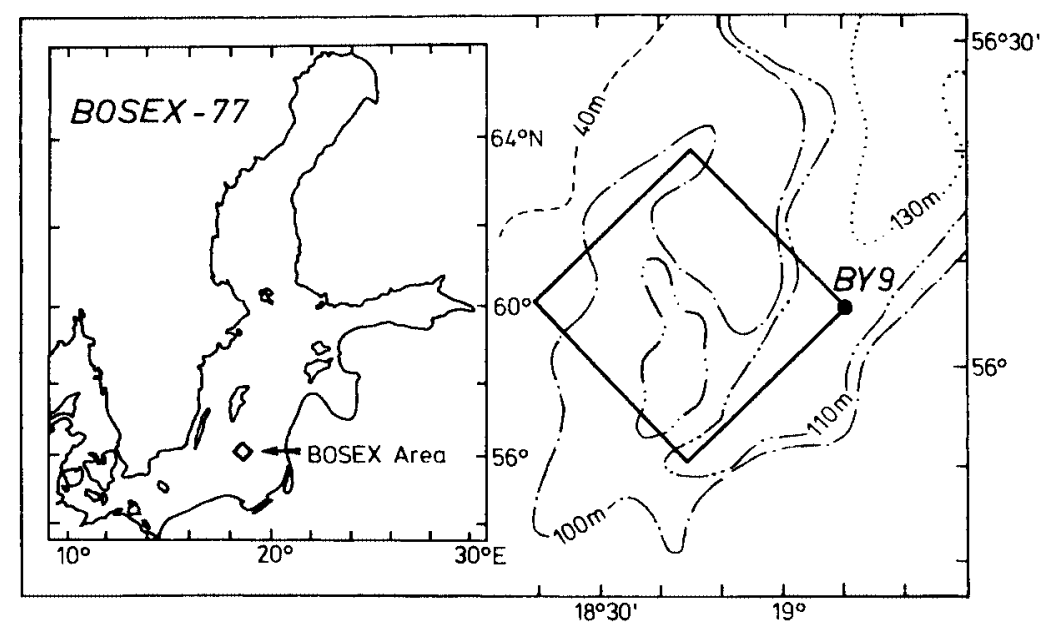

Fig. 3. Map showing the site of the square worked during BOSEX 1977 (Matthäus, 1987).

During the second week BOSEX was unfortunate being disturbed by a severe storm with wind forces above $36 \mathrm{~m} / \mathrm{s}$ and therefore the scientific results were rather limited. On the Aranda from Helsinki two sailors were injured when thrown against the anchor winch while trying to secure the anchor. They had to be transported to a hospital in Visby by helicopter. The Aju Dag had many of its instruments smashed during an attempt to turn up against the wind and went to Copenhagen for shelter. The Poseidon from Kiel had engine trouble and had to go to Rønne on Bornholm for repairs. All small ships had to go for shelter in Gdynia. Finally only the Professor Albrecht Penck from Warnemünde and the Argos from Göteborg remained in the working area. However, sampling and laboratory work were impossible in the hard weather with very high waves and both ships decided to go to Gdynia. Nevertheless, important results were obtained regarding the response of the Baltic Sea to severe storms in the BOSEX area. Some 16 papers with results from BOSEX-77 were presented at the CBO XI in 1978 and in ICES (ICES, 1984).

\section{PATCHINESS EXPERIMENT}

During the late 1970s a significant discussion subject in the ICES/SCOR Working Group was the spatial heterogeneity ("patchiness") of hydrographic and marine biological factors in the Baltic Sea. This long known phenomenon had become more evident with the increasing use of satellite images in oceanographic research. Important questions to be looked into were geographical distribution of patchiness parameters and temporal variations. Other questions were how patchiness could interfere with monitoring and other trend investigations in the 
field, and the origin, evolution, and dynamics of patchiness. In 1980 the Working Group suggested that an in depth study of the problem complex should be initiated.

Scientists representing several countries started investigations. These were supported by CBO and BMB. A cooperative study was made in 1982 in the BOSEX region by three research vessels: the Argos, the Poseidon, and the Aju Dag. Estonian scientists were thus involved from the beginning on the initiative of the ICES/SCOR Working Group member A. Aitsam from the Institute of Thermophysics and Electrophysics in Tallinn. On board the Aju Dag were among others the Estonian scientists J. Elken and V. Kraav. At the 1982 meeting of the Working Group, Aitsam invited the Group to have its 1983 meeting in Tallinn. It was decided to arrange a Workshop on Patchiness during two days before the meeting. At this Workshop some of the papers had authors from Tallinn. The great Estonian interest in patchiness investigations was expressed by I. Öpik from the Academy of Sciences of the Estonian SSR.

The Workshop participants suggested the setting up of a special body for handling the future patchiness studies and in 1983 ICES established the Study Group on Patchiness Investigations in the Baltic. During a series of meetings and with much correspondence between the meetings, a multiship experiment was planned. The planning took several years with participation of all Baltic countries. From the USSR all three Baltic republics as well as Moscow were represented with a heavy weight on Tallinn. In April 1985 four ships, among them the new Arnold Veimer from Tallinn, made a preliminary study, the PRE-PEX, to gain experience before the final experiment.

In two meetings of the ICES Study Group in late 1985 and early 1986 the programme for the comprehensive field experiment was agreed upon, and the Patchiness Experiment (PEX-86) was carried out in an area south of Gotland close to the BOSEX area from 20 April to 10 May 1986 by a total of 12 ships (a few of them made also additional investigations outside the main programme). All ships had definite tasks, most repeatedly followed sections in two grids with regular distances in space and time. Other ships were anchored or made special investigations (Fig. 4). On all stations hydrographic and biological parameters were sampled at different depths. When the results were put together, a fourdimensional picture of the area was obtained, which allowed the definition of eddies, fronts, jetstreams, etc. The Arnold Veimer from Tallinn became one of the key ships because it was new and well equipped and its scientists had ample experience of similar investigations. The whole experiment was coordinated from the Swedish Argos. The main link was meeting per radio every morning, but ships were so close to each other that direct contacts and transfer of preliminary results by means of motorboats were possible. Before the field experiment in the investigation area an intercalibration of methods between the ships was made in the port of Karlskrona in southern Sweden.

The processing of the results took several years. It was done in the framework of the ICES Study Group of Patchiness Investigations in the Baltic, which after 


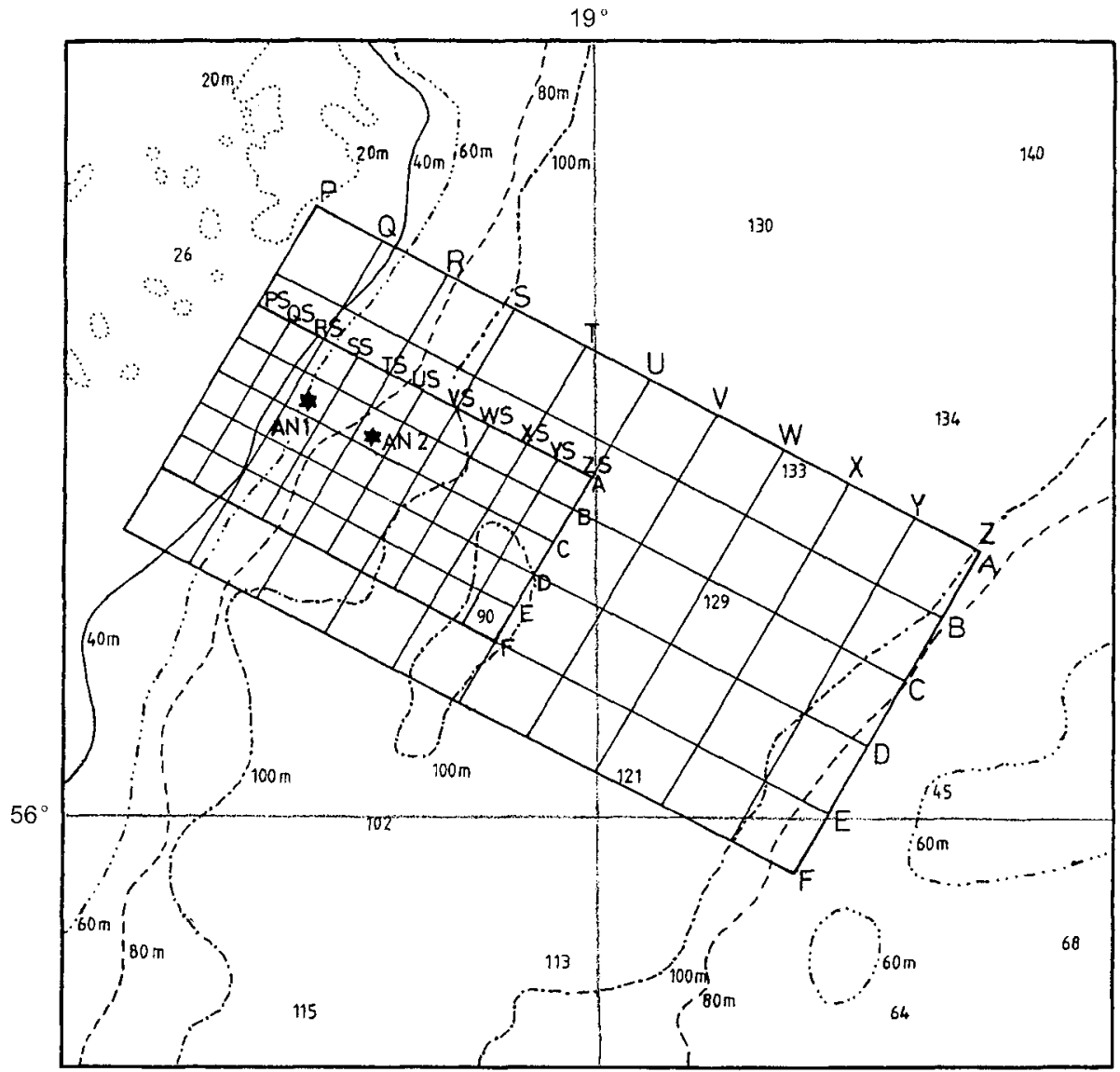

Fig. 4. The two station grids and the anchor stations used in the Patchiness Experiment in 1986 (ICES, 1989).

the closing down of the ICES/SCOR WG, reported to the ICES WG on Baltic Environment and to the ICES Hydrography Committee. The draft for a report on the results was made at a meeting in Wustrow in GDR in 1988. Among the 50 participants 7 were from the Estonian SSR. The report on PEX-86 was then published by ICES (ICES, 1989). In 1992 the data from PEX were compiled to a PEX Atlas stored on diskettes. This work was carried out at the then Institute of Ecology and Marine Research of the Estonian Academy of Sciences (ICES, 1992). The last cooperative project related to PEX-86 was the arranging of a Symposium on Patchiness in the Baltic in Mariehamn, the Åland Islands, in June 1991. Altogether 35 papers were presented of which 18 were published in a volume by ICES (ICES, 1994). PEX data have also been used in papers published in other connections by authors from several countries, including Estonia. 
The PEX was very successful in investigating physical, chemical, and biological patchiness in time and space during the phytoplankton spring bloom. Furthermore, the whole process involving planning, intercalibrations, field investigations, and the processing of the tremendous amount of data, all involving more than 100 scientists, gave besides the scientific results a very valuable experience of international cooperation of countries sharing a common sea area but situated within two different political blocs. On the whole the Estonian input was massive considering the smallness of the country and the political transformation which the country was undergoing at that time.

\section{THE SKAGERRAK EXPERIMENT}

Already at an early stage after PEX there was a wish to preserve the technical capability of cooperation obtained among the Baltic scientists. After some discussions it was agreed to carry out another joint international multiship investigation, this time in the entrance area of the Baltic Sea, mainly in the Skagerrak area, which has a great importance for the Baltic itself, and thus for Baltic research. The conditions in the area were known to be very complex and not especially well known. The new project, called the Skagerrak Experiment (SKAGEX), was adopted by ICES at the Statutory Meeting in October 1989. Three regular planning meetings were held in 1989 and early 1990. The SKAGEX covered the Skagerrak area and partly also the Kattegat. In addition to most of the Baltic Sea countries also Norway participated. A SKAGEX manual was produced with detailed guidelines for:

Positions, depths, dates, and names of responsible research vessels;

Cross-sections, positions, depths, dates, starting points, and times for sampling the sections by the allocated research vessels, current meter moorings, procedure for intercalibrating conductivity-temperature-depth recordings;

Stations for hydrographical, chemical, and biological sampling;

Physical and chemical parameters;

Phytoplankton measurements, in situ fluorescence, chlorophyll $a$;

Zooplankton measurements;

Presentation of data.

The experiment was divided in four parts: SKAGEX I in May-June 1990 (15 ships), SKAGEX II in September 1990 (5 ships), SKAGEX III in January 1991 (3 ships), and SKAGEX IV in May 1991 (6 ships). Altogether 17 research ships participated during different periods, representing Denmark, Estonia, FRG, GDR, Lithuania, Norway, Poland, Russia, and Sweden. In the middle of SKAGEX I, 13 participating ships met in the harbour of Arendal for intercalibration of methods.

The map in Fig. 5 shows the area and the transects (Danielssen et al., 1997). Remote sensing was also a part of the experiment. LANDSAT 5, measuring the radiance in the visible and infrared electromagnetic bands, passed over the 


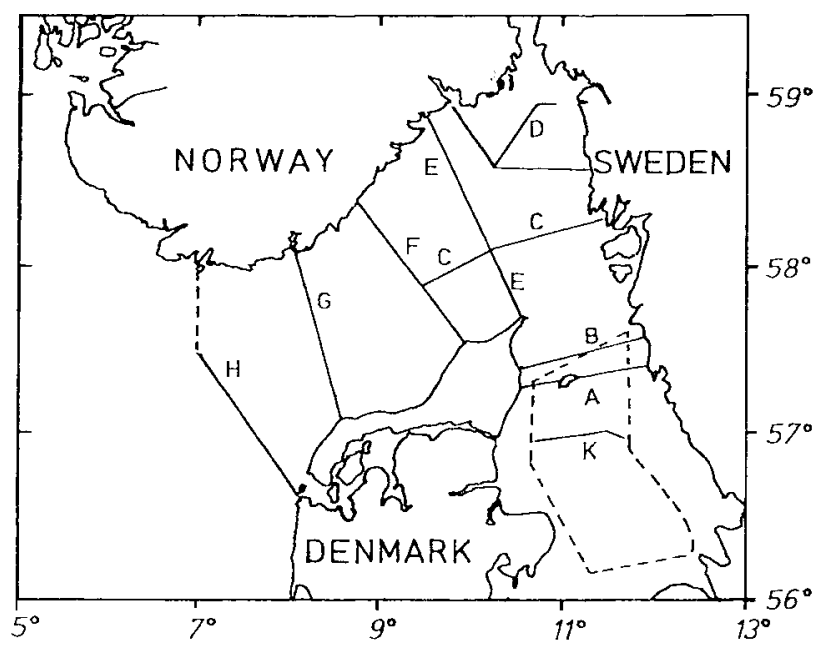

Fig. 5. Map of the Skagerrak and Kattegat showing the stations and sections of the Skagerrak experiment (Føyn, 1999).

SKAGEX area several times during SKAGEX I and samples were taken at the passing times by participating research vessels for measuring Secchi disk depth, chlorophyll, humus, and total suspended matter for comparison with the LANDSAT data.

A computerized SKAGEX data handling system, the SKAGEX Atlas, and a users' guide to the Atlas were elaborated by Ostrowski (1994). A finalizing workshop was held in Lysekil, Sweden, in October 1992 (Føyn, 1999). Reviews of SKAGEX and the preliminary results have been published by Dybern et al. (1994) and Danielssen et al. (1997). The SKAGEX Atlas is free for every interested scientist to use after contact with ICES, Copenhagen, where it is deposited. Data are well fit for studies of the distribution, variation, and nature of the Skagerrak water masses, the distribution and variability of plankton and nutrients, and for patchiness studies.

The Estonian input to SKAGEX was made during the time of political liberation and reorganization of Estonian science. The input was nevertheless important thanks to the experience of the participating scientists. Several Estonian publications emanate from the SKAGEX data.

\section{OTHER RECENT INTERNATIONAL COOPERATION}

The Baltic Sea System Study (BASYS) was mainly carried out in 1994-98 and constituted an umbrella programme for a large number of mainly national projects in climatology, hydrography, marine biology, palaeobiology, etc. with participation of institutes in all Baltic Sea countries. BASYS was supported by 
the European Union among others. More or less co-planned and co-existing with BASYS was the Gotland Basin Experiment (GOBEX), a multiship investigation carried out in the mid-1990s with participation of several Baltic Sea states. The main aim was to investigate the distribution of environmental factors in the area between Latvia and the island of Gotland. In some way this project falls in the same category of undertakings as IBY, BOSEX, etc.

In spite of all investigations made in the Baltic Sea the lack of knowledge of the structure and functioning of the Baltic ecosystem as a whole was pointed out and in the mid-1990s discussions on starting a study of the Baltic Sea large marine ecosystem (BSLME) began. The study should be conducted in conjunction with similar undertakings in other parts of the world within a system sponsored by the Global Environmental Facility (GEF) which, in turn, gets its funds inter alia from the World Bank. Due to unforeseen events the Baltic project has been delayed and presently (2001) seems to be transformed into a more applied environmental and resource-directed scheme. Estonia has shown interest in both BASYS and BSLME. It is also engaged in regional projects in the Gulf of Finland and the Gulf of Riga.

\section{SUMMARIZING DISCUSSION}

The Baltic Sea is one of the most thoroughly investigated marine areas in the world. While early research was mainly national, more recent investigations have become increasingly internationalized, among other things due to the fact that the Baltic Sea is a property shared between a number of countries. Baltic marine investigations are also, as marine projects elsewhere, becoming more extensive and too expensive for single countries to carry out.

Estonian research in the Baltic Sea can be said to have started with the work of K. E. von Baer, who in the middle of the 19th century studied the interplay between the fish stocks, their environment, and the fishery (Järvekülg, 1962; Ojaveer et al., 2000). He worked widely within the then Russian empire and had many contacts with other countries.

At the beginning of the 20th century ICES was established and became the dominating international organization in the Baltic Sea up to World War I and during the interwar period. At that time the Estonian research was mainly conducted at the University of Tartu and mostly devoted to fresh waters. During the first period of independence Estonia participated in some hydrographic work in the Baltic Sea, and one of the hydrographic conferences during the interwar period was held in Tallinn. There were also some international contacts on fisheries questions and Estonia joined ICES, but withdrew after a couple of years in 1925, evidently for financial reasons.

During the first decades after World War II scientific activities were successfully rebuilt, especially in Tartu, but gradually also in Tallinn. Most hydrological and hydrobiological work was still mainly devoted to fresh waters. Papers covering 
different limnological aspects were published. The harsh political conditions, which hampered international contacts in the Estonian SSR during many years, have been described by Ojaveer et al. (2000). Activities in the coastal areas seem to have been very closely controlled by Soviet authorities, but gradually projects were performed also there, and an increasing number of marine science papers were published in the 1960s and 1970s. During that time Estonian scientists again got connected to ICES (via USSR authorities), especially concerning matters of fish stocks and pollution. Even during this restrictive time Estonian scientists seem to have been well familiar with the results of foreign research, as shown by comprehensive foreign literature lists in their marine science publications.

The establishment of the Institute of Thermophysics and Electrophysics and the placing of the research vessel Aju Dag in Tallinn in the 1970s created a base for marine scientists and better possibilities than earlier for research on the sea and travelling. International contacts, e.g. with ICES, grew and Estonian scientists began to participate in $\mathrm{CBO}$ and later in BMB activities. Bilateral cooperation between the USSR and adjacent countries and the creation of the Baltic Fisheries Commission in 1974 and of the Helsinki Commission in 1980 (interim commission from 1974) contributed to increasing the international contacts. A large number of Estonian scientists participated during the late 1970s and the 1980s in Baltic meetings and in international projects such as BOSEX, PEX, and SKAGEX and gained respect for their knowledge and input. The Aju Dag was substituted by the bigger and more modern Arnold Veimer (later the Livonia). Of course, the continuously improving political situation towards the end of this period also helped. When in 1991 Estonia regained total freedom, this trend continued. Estonia is now full member of ICES and other international marine organizations and has participated in several recent activities, e.g. in the modelling of the Baltic Sea environment and the BASYS project. However, as is the case for most Baltic Sea countries, the financial situation became strained for Estonia during the 1990s. This has led to the sale of the Livonia. On the other hand, the new Estonian Marine Institute in Tallinn and increasing marine activities in Tartu and Pärnu with many dedicated scientists involved, are a guarantee that Estonia will continue to play an important role in Baltic research.

\section{ACKNOWLEDGEMENT}

The authors wish to acknowledge the valuable suggestions by two Estonian referees.

\section{REFERENCES}

Anon. 1878. Nautisk-meteorologisk Konference i Kjøbenhavn mellem Delegerede fra Norge, Sverige og Danmark 1878. Kongelige danske Søkartearkiv. J. H. Schultz, Copenhagen.

Anon. 1892. Forhandlingar ved de scandinaviske Naturforskeres 14 Møde. J. Jørgensen \& Co., Copenhagen. 
Andrušaitis, A. (ed.) 1997. Proceedings of the 13th Baltic Marine Biologists Symposium. Institute of Aquatic Biology, University of Latvia.

Arndt, E. A. 1969. Tagungsbericht. Limnologica, 7, 3-7.

Danielssen, D. S., Edler, L., Fonselius, S., Hernroth, L., Ostrowski, M., Svendsen, E. \& Talpsepp, L. 1997. Oceanographic variability in the Skagerrak and Northern Kattegat. May-June 1990. ICES J. Marine Sci., 54, 753-773.

Dybern, B. I. 1972. Pollution in the Baltic. In Marine Pollution and Sea Life (Ruivo, M., ed.), pp. 15-23. Fishing News (Books) LTD, West Byfleet, London.

Dybern, B. I., Danielssen, D. S., Hernroth, L. \& Svendsen, E. 1994. The Skagerrak Experiment. SKAGEX report 1988-1994. Tema Nord, 635, 1-34.

Fonselius, S. 2001. Hydrographic investigations in the Baltic Sea area before the founding of ICES. ICES Marine Science Symposia (in press).

Føyn, L. (ed.) 1999. SKAGEX, The Skagerrak Experiment. Introduction. Fisken og havet, 9.

ICES 1970. Report of the ICES Working Group on Pollution of the Baltic Sea (Dybern, B. I., ed.). ICES Coop. Res. Rep., Ser. A, 15.

ICES 1984. Overall Report on the Baltic Open Sea Experiment (BOSEX) (Kullenberg, G., ed.). ICES Coop. Res. Rep., 127.

ICES 1989. Baltic Sea Patchiness Experiment (PEX-86). Part I (Dybern, B. I. \& Hansen, H. P., eds.). ICES Coop. Res. Rep., 163.

ICES 1992. Baltic Sea Patchiness Experiment - PEX-86. Part II. Atlas (Elken, J., Lips, U., Talpsepp, L. \& Väravas, H., eds.). Tallinn.

ICES 1994. Patchiness in the Baltic Sea. Selected papers from a symposium held in Mariehamn 3-4 June 1991 (Dybern, B. I., ed.). ICES Coop. Res. Rep., 201.

Järvekülg, A. 1962. K. E. Baer kalandusbioloogiliste uurimiste rajajana Venemaal. Eesti NSV TA Hüdrobiol. Uurim., III, 21-23.

Matthäus, W. 1987. The history of the Conference of Baltic Oceanographers. Beitr. Meeresk., 57, $11-23$.

Ojaveer, E. 1997 (ed.) Proceedings of the 14th Baltic Marine Biologists Symposium. Estonian Academy Publishers, Tallinn.

Ojaveer, E., Rannak, L. \& Laevastu, T. 2000. One and a Half Centuries of Sea and Fisheries Investigations in Estonia. Estonian Academy Publishers, Tallinn.

Ostrowski, M. 1994. The SKAGEX Atlas. Tema Nord, 665, Part II, 33-99. Copenhagen.

Went, A. 1972. Seventy years of agrowing. A history of the International Council for the Exploration of the Sea 1902-1972. Rapp. P.-v. Réun. Cons. int. Explor. Mer, 165. Copenhagen.

\section{LÄÄNEMEREGA SEOTUD RAHVUSVAHELINE MERETEADUSLIK TEGEVUS JA EESTI OSALUS SELLES}

\section{Bernt I. DYBERN ja Stig FONSELIUS}

Mere ja magevete uuringud algasid Eestis 19. sajandil. Eesti teadlased on tegelnud selle valdkonnaga nii poliitilise vabaduse tingimustes kui ka Vene ja Nõukogude Liidu võimu all. Võimaluse korral on osa võetud rahvusvaheliste organisatsioonide tööst ning Läänemere uurimise rahvusvahelistest projektidest. Pärast taasiseseisvumist on Eesti mereteadlased jäänud aktiivseks vaatamata reorganiseerimistele ja finantsraskustele. 